\title{
光化学表面改質法により形成した自動車用樹脂空の耐摩耗性向上
}

\author{
野尻 秀智 ${ }^{1,2}$, 大越 昌幸 ${ }^{1}$ \\ 1P防衛大学校電気情報学群電気電子工学科 ( ₹239-8686 神奈川県横須賀市走水1-10-20) \\ ²株式会社レニアス（７29-0473 広島県三原市沼田西町小原200-76)
}

\section{Improvement of Abrasion Resistance of Automotive Resin Window Fabricated by Means of Photochemical Surface Modification}

\author{
Hidetoshi NOJIRI ${ }^{1,2}$ and Masayuki OKOSHI ${ }^{1}$ \\ ${ }^{1}$ Department of Electrical and Electronic Engineering, National Defense Academy, 1-10-20 Hashirimizu, Yokosuka, Kanagawa 239-8686 \\ ${ }^{2}$ Renias, Co., Ltd., 200-76 Obara, Nutanishi, Mihara, Hirosima 729-0473
}

(Received March 22, 2018)

\begin{abstract}
Silicone-coated polycarbonate was photochemically modified into $\mathrm{SiO}_{2}$ by a $157-\mathrm{nm}$ fluorine laser for developing an automotive resin window to satisfy United Nations Economic Commission for Europe (UNECE) regulations for the abrasion resistance of $\Delta H_{1000} \leqq 2 \%$. We considered a mesh mask. With it, we improved the abrasion resistance by increasing the laser irradiation time to less than $30 \mathrm{~s}$; by increasing the laser irradiation, the abrasion resistance decreased. We revealed that abrasion resistance can be suppressed by lowering the opening length of the mesh mask using laser irradiation through it. By suppressing the stress caused by the photochemical modification by setting the distance between the mesh mask and the sample surface, good abrasion resistance less than $2 \%$ was obtained for any laser irradiation time at $20 \mathrm{~mm}$.
\end{abstract}

Key Words: $\mathrm{F}_{2}$ laser, Silicone, $\mathrm{SiO}_{2}$, Abrasion resistance, Automotive window

1.はじめに

ケイ素は地球上に豊富に存在する物質であり，その化 合物の利用は多岐にわたっている。特に酸化物であるシ リカ $\left(\mathrm{SiO}_{2}\right)$ は光学的透明性が高く ${ }^{1)}$, 化学的にも安定で あり ${ }^{2)}$, 電気的・機械的特性にも優れている ${ }^{3)}$.このた め, 半導体応用から医療分野に至るまで, 様々な形態で 利用されている。 また，有機ケイ素化合物もシリコーン を代表として, 生体材料 ${ }^{4}$ や化粧品など, 生活と密着し ている.

一方, 環境保全の見地から, $\mathrm{CO}_{2}$ を中とした温室効 果ガスの削減が世界的に取り組まれ，自動車のゼロエ ミッション化が危急の問題となっている5 . このため, 自動車からの排出ガス低減のみならず，個々の部品の製 造工程における無排出化やプロセスの低温化などのニー ズが高まっている。 ポリカーボネート (Polycarbonate: PC) は，ゼロエミッション化を実現するための有用な材 料の 1 つ考えられており, それはPCの有する軽量性や 耐衝撃性, 加工性に因る ${ }^{6,7)}$. しかし一般にPCは, 耐摩耗 性や耐薬品性, 耐候性にそしく，その表面をケイ素化合 物, すなわちシリコーンやシリカで被覆し保護膜とする 方法が検討され ${ }^{8,9)}$, これをハードコートと称している.

ところで，PCが自動車用樹脂空として利用できるよう になったのは，1994年に自動車空ガラスの保安基準が策
定されてからである ${ }^{10)}$ 。そして2017年6月の道路運送法 の保安基準の改定において, 樹脂製フロントガラスの使 用が認められ，すべての部位の空ガラスに樹脂の使用が 可能となった。このように，PCを自動車用空材に使用す るための環境が整った。しかしながら，実際の使用にお いては，国連経済委員会(UNECE)が定めた規格を満た す必要があるが, 従来の一般的なハードコートは, 特に 運転視界に係るフロントや，フロントサイドおよびリア ウィンドウに使用される用途において耐摩耗性が不足す る. 加えて, 自動車のフロントガラスとしての使用で は, 頭部衝撃值が所定值未満であることも必要となる.

著者らは, シリコーンの真空紫外レーザーによる光化 学表面改質法に着目し ${ }^{11,12)}$ ，シリコーンの組成改質のみ ならず，シリコーン表面の形状制御にまでその応用範囲 を広げた ${ }^{13-15)}$ 。そして, 耐摩耗性, 耐熱性, 耐候性およ び耐薬品性を有する自動車用PC樹脂空を開発するため に，波長 $157 \mathrm{~nm}$ のF $\mathrm{F}_{2}$ レーザーをシリコーンハードコート 表面に照射し, 光化学的に形成される $\mathrm{SiO}_{2}$ 改質膜を, 自 動車用樹脂窓に適用するための検討を行った ${ }^{16-18)}$ 。しか し, $\mathrm{SiO}_{2}$ 改質膜には応力が内在しやすく, 膜厚の増加, および耐熱性や耐候性の試験において，クラックが生じ やすいことが明らかとなり，その改善方法を検討し報告 した ${ }^{19-21)}$.

本論文では，PCを自動車用樹脂空として実用化するこ 
とを目的に， $F_{2}$ レーザーを試料に照射する際，メッシュ マスクと試料との距離を変化させることにより, 耐摩耗 性が向上できることを見出した結果について紹介する.

\section{2. 実 験}

\section{1 試料の調製およびレーザー照射}

大きさ $100 \times 150 \mathrm{~mm}^{2}$ ，厚さ $3 \mathrm{~mm}$ の透明 $\mathrm{PC}$ 板に，アク リル樹脂ならびにシリコーン樹脂(帝人, DMT250)を， ディップコーター(Aiden, DC4300)により順次塗布し た。アクリル樹脂の塗布後には $125^{\circ} \mathrm{C} 60 \mathrm{~min}$ またシリ コーン樹脂の塗布後には $120^{\circ} \mathrm{C} 60 \mathrm{~min}$ の硬化を, 熱風乾 燥炉 (ONDO, TD15-12M) 中にて行った。上により，ア クリル樹脂とシリコーン樹脂を, ともに膜厚 $4 \mu \mathrm{m}$ でPC 上に積層した。 さらに，これを $100 \times 100 \mathrm{~mm}^{2}$ の大きさ に切断し試料とした.

ここでアクリル樹脂層は, シリコーン樹脂とPCの中 間的な硬度を有し, 各層間の応力緩和や, シリコーン樹 脂とPCとの密着性を確保するために塗布した。

Fig. 1 に, 実験の構成を示す。試料を, モーター駆動 のX-Yステージ (シグマ光機, SGSP26-100XY) 上に設置 し，上方より $\mathrm{F}_{2}$ レーザー (Coherent, LPF pro205)を照射し た。レーザーの出射口には，開口サイズが $10 \times 10 \mathrm{~mm}^{2}$ のステンレス製のマスクを設け，レーザー光を，均一性 の高い出射口の中心付近のみに制限した。また，出射口 と試料との間にステンレス製のメッシュマスクを設置し た。出射口とステンレスマスクの距離 $d_{1}$ は $5 \mathrm{~mm}$ と, メッシュマスクと試料表面の距離 $d_{2}$ は0-20 mmで変化さ せた。このとき, 出射口と試料間の距離は $d_{2}$ の設定によ り変化することになる。 メッシュマスクは, 試料端4か 所の角部に設けたスペーサーに固定した。 また，スペー サー先端とステンレスマスクの距離は $2 \mathrm{~mm}$ とし, 図示 していないが，スペーサーと同じ高さの囲いを設けた。 これにより, 光路中に導入する $\mathrm{N}_{2}$ ガスの酸素パージ効 果を高めた，レーザーの照射条件は，単一パルスのフル エンス $10 \mathrm{~mJ} / \mathrm{cm}^{2}$, パルス繰り返し周波数 $10 \mathrm{~Hz}$, 照射時 間 $15-90 \mathrm{~s}$ とた。 $\mathrm{N}_{2}$ ガス流量が5 L/minの場合, $d_{2}$ が20 mmのときにおけるエネルギー密度の低下は, $d_{2}$ が0 mmの場合に比較し10\%程度と測定された。 Table 1 に，使用したメッシュマスクの種類を示す。メッ シュの公称名と開口長は厳密には一致しないが, 以下,

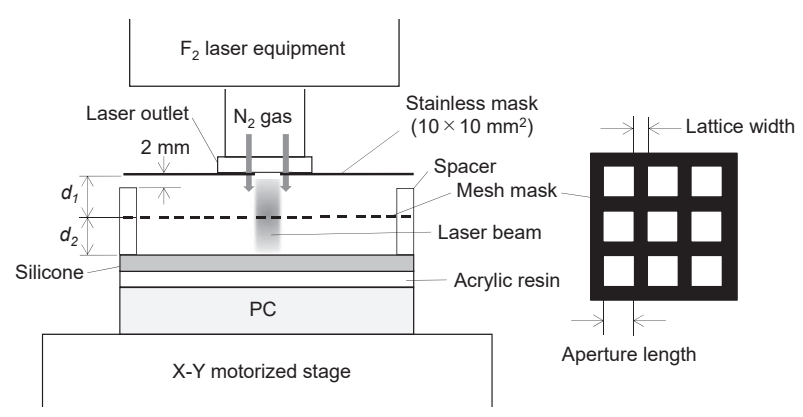

Fig. 1 Illustration of the experimental apparatus for $\mathrm{F}_{2}$ laser irradiation with mesh mask.
Table 1 Types of the mesh mask.

\begin{tabular}{ccccc}
\hline $\begin{array}{c}\text { Mesh } \\
\text { (Nominal) }\end{array}$ & $\begin{array}{c}\text { Aperture } \\
\text { length }\end{array}$ & $\begin{array}{c}\text { Lattice } \\
\text { width }\end{array}$ & $\begin{array}{c}\text { Mesh } \\
\text { number }\end{array}$ & $\begin{array}{c}\text { Aperture } \\
\text { ratio }\end{array}$ \\
\hline $50 \mu \mathrm{m}$ & $30 \mu \mathrm{m}$ & $18 \mu \mathrm{m}$ & 400 & 0.39 \\
\hline $150 \mu \mathrm{m}$ & $156 \mu \mathrm{m}$ & $87 \mu \mathrm{m}$ & 100 & 0.4 \\
\hline $300 \mu \mathrm{m}$ & $250 \mu \mathrm{m}$ & $130 \mu \mathrm{m}$ & 60 & 0.43 \\
\hline $1 \mathrm{~mm}$ & $940 \mu \mathrm{m}$ & $275 \mu \mathrm{m}$ & 20 & 0.59 \\
\hline $5.5 \mathrm{~mm}$ & $5.5 \mathrm{~mm}$ & $0.8 \mathrm{~mm}$ & 4 & 0.76 \\
\hline
\end{tabular}

本論文では公称名を使用する。

Fig. 2 に $\mathrm{F}_{2}$ レーザーのビーム走査方法を示す. $\mathrm{F}_{2}$ レー ザーの元のビームサイズは約 $10 \times 24 \mathrm{~mm}^{2}$ で水平方向に 長い長方形となっており, 水平方向がフラットトップ, 垂直方向がガウス関数の強度分布を有している。ここ で, $10 \times 10 \mathrm{~mm}^{2}$ のステンレスマスクを使用することに より, 水平方向はほぼフラットで, 垂直方向には半值全 幅(Full Width at Half Maximum: FWHM)が，マスクの開 口幅に相当する範囲とした。従って，レーザー光を走査 する場合は，垂直方向に一定速度で走査することによ り, ビームサイズ $\left(10 \times 10 \mathrm{~mm}^{2}\right)$ 内の平均フルエンスを 一定值に保持した。レーザー光の走査は，X-Y電動ス テージの駆動により行った。 $10 \mathrm{~mm}$ 幅のライン走査後, 隣のラインへの移動は $30 \mathrm{~mm} / \mathrm{s}$ 以上の速度で素早く行う ことにより過照射を防いだ。以上により，100× $100 \mathrm{~mm}^{2}$ の試料表面全体に均一にレーザー光を照射し た。

なお，使用したメッシュマスクはTable 1 に示したも のとしたが, 比較のためにメッシュマスクを使用しない 場合，およびレーザー光の照射を行わない試料も作製し た。

\section{2 テーバー摩耗試験}

試料表面の耐摩耗性を評価するために，テーバー摩耗 試験を行った。この試験は，ASTM D1044やJIS K7204等 の工業規格で規定された，透明部材の傷付きに対する耐 性を評価するための試験方法である。米国テーバー社製 の摩耗輪を使用することが規定されており，テーバー摩 耗試験と呼ばれる。本試験では, 摩耗試験器 (東洋精機, TS型)の回転テーブル上に試験用試料を固定し,さらに 試料表面上に2個一対の摩耗輪 (テーバー社, CS-10F type IV)を500 gの荷重をかけて設置した。この状態で，回転

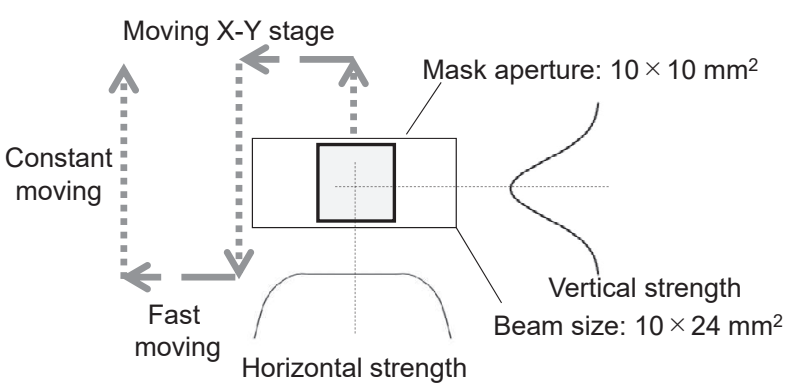

Fig. 2 Method of laser scanning by moving of the X-Y motorized stage. 
テーブルを一定速度にて1000回転させ，試料表面におけ る光学的なへイズ変化 $\Delta H_{1000}(\%)$ を, ヘイズメーター （日本電色，NDH4000）にて測定した. $\Delta H_{1000}$ は, 数值が 低いほど優れた耐摩耗性を示し，UNECEにおいては， $\Delta H_{1000} \leqq 2 \%$ 自動車における運転視界に係る部位におけ る空の規格とされている ${ }^{22)}$.

\subsection{FT-IRおよびフッ酸エッチングによる評価}

$90 \mathrm{~s}$ のレーザー照射後における，メッシュマスクの開 口部の内側および外側を，顕微プリズムを用いたフーリ 工変換型赤外分光法 (Fourier Transform Infrared Spectrometer: FTIR, Jasco, FT/IR-6600typeA)により測定した。こ のとき測定のスポット径が約 $5 \mu \mathrm{m}$, 測定間隔 $2.2 \mu \mathrm{m} に て$ 水平および垂直方向に各32点, 計64点の測定を行い, 面 積が約 $70 \times 70 \mu \mathrm{m}^{2}$ のマッピング情報を得た。このマッピ ング情報から波数 $1020 \mathrm{~cm}^{-1}$ 付近のSi-Oの吸収ピークの高 さに対する $1273 \mathrm{~cm}^{-1}$ の $\mathrm{Si}-\mathrm{CH}_{3}$ に由来する吸収の高さの比 を求めてグレースケールマップを作成するとともに, $\mathrm{Si}-\mathrm{O}$ の吸収ピークの組成変化に伴うシフトを測定するこ とにより,メッシュマスクの開口端部に拈ける水平方向 の組成変化を求めた.

また，試料を濃度1\%のフッ酸水溶液 $(\mathrm{HF})$ に $10 \mathrm{~min}$ 浸 漬し， $\mathrm{SiO}_{2}$ 改質層を化学エッチングにより除去し，その 後に形成された段差を, 触針式表面粗さ計 (Veeco, DE$\left.\mathrm{TAK}^{3}\right)$ を用いて測定することにより $\mathrm{SiO}_{2}$ 改質層の厚さを 求めた。ささらに, 光学顕微鏡 (Nikon, ECLIPSE VL100) により，試料表面の状態を観察した。

\section{3. 実験結果および考察}

\section{1 耐摩耗性試験の結果}

Fig. 3 に, メッシュマスクの開口長を変化させたとき の, テーバー摩耗試験の $\Delta H_{1000}$ のレーザー照射時間依存 性を示す。このときFig. 1 に示した実験構成図におい て, メッシュマスクと試料表面の距離 $d_{2}$ は $0 \mathrm{~mm}$ で密着 状態とした。レーザーの照射を行わない場合, すなわち レーザー照射時間が $0 \mathrm{~s}$ の場合, $\Delta H_{1000}$ は7\%程度を示した が，レーザー照射時間の増加とともに低下し，レーザー 照射時間が15-30sのときに最小值を示し, 以後

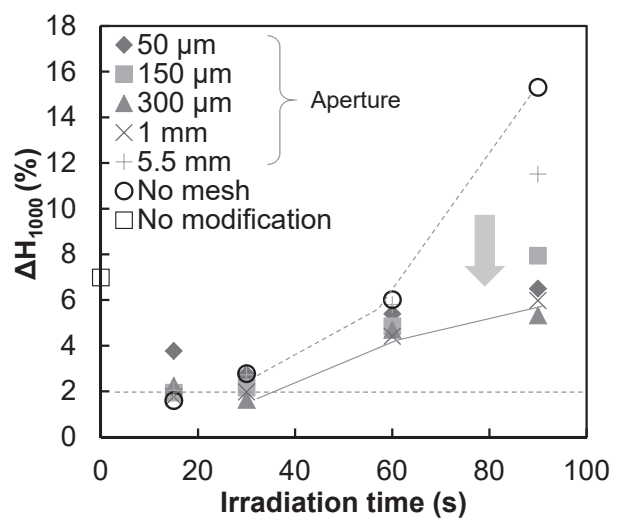

Fig. 3 Result of the Taber abrasion test with laser irradiation using mesh mask.
$\Delta H_{1000}$ は増加に転じた。特に，メッシュマスクを使用し

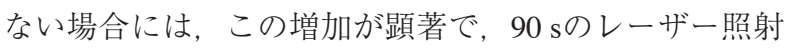
時間において $\Delta H_{1000}$ は約 $15 \%$ を示した。 これに対し, メッシュマスクを使用した場合は, レーザー照射時間 が30 s以下においては，メッシュマスクを使用しない場 合と同様に $\Delta H_{1000}$ の低下傾向を示したが, $60 \mathrm{~s}$ 以上にお ける $\Delta H_{1000}$ の増加はメッシュマスクを使用しない場合に 比較し低い值にとどまった。そしてこの傾向は, 特に メッシュマスクの開口長が小さな場合に顕著であった。

以上のことから, 開口長が小さなメッシュマスクを使用 することにより，より低い $\Delta H_{1000}$ が得られることが明ら かとなった。

しかしながら，以上の結果によれば，自動車の空とし

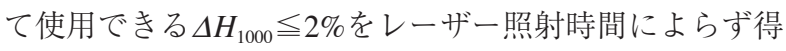
ることは難しい. 本来, レーザー照射時間の増加ととも に, $\mathrm{SiO}_{2}$ 改質層の厚みが増加するため ${ }^{19)}$, 耐摩耗性は向 上するはずであるが，期待したような結果が得られな かった。これは， $\mathrm{SiO}_{2}$ 改質層の形成時にシリコーンが収 縮することにより引張応力が生じ, この応力は膜厚の増 加とともに増大するため, これにテーバー摩耗試験時の 荷重による応力が加わり, 結果的に $\mathrm{SiO}_{2}$ の破壊強度に達 したものと推測する。以上のようにテーバー摩耗と内部 応力は密接に関係していると考えられる。

Fig. 4 は, Fig. 3 の結果において, 横軸にメッシュマ スクの開口長をとって示したグラフである。レーザー照 射時間が決まれば， $\Delta H_{1000}$ はメッシュの開口長によらず ほぼ一定值を示したが, 特に開口長の小さな50 $\mu \mathrm{m} の$ メッシュマスクの場合に若干高い $\Delta H_{1000}$ が測定された。

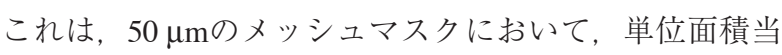
たりのすべての開口部の周辺長の積算值が, $150 \mu \mathrm{m} の$ メッシュの約5倍, $1 \mathrm{~mm}$ のッシュの約 20 倍になってお り, その分, 開口部の端部に生ずる引張応力が大きいた めに耐摩耗性が低下したものと考えられる.

\section{2 耐摩耗性におけるメッシュマスクと試料表面間} の距離の依存性

Fig. 5 は, $\mathrm{SiO}_{2}$ 改質層の傾斜組成を示す模式図であ る. Fig. 5 (a) はメッシュマスクを試料表面に密着させた 場合で, Fig. 5(b)は試料表面より距離 $d_{2}$ だけ上方に離し

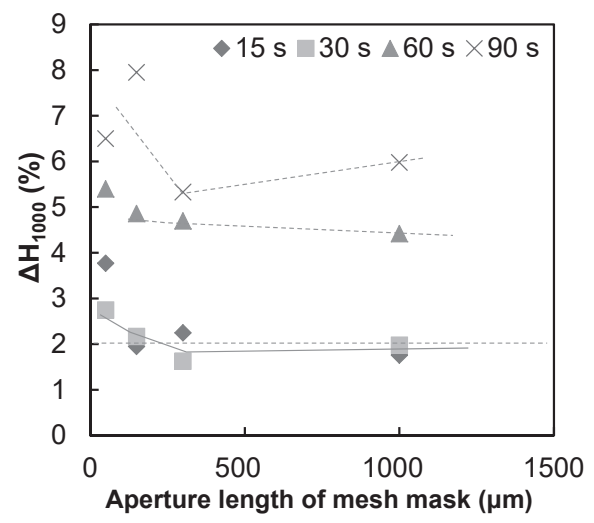

Fig. 4 Result of the Taber abrasion test with laser irradiation depends on aperture length of mesh mask. 
(a)

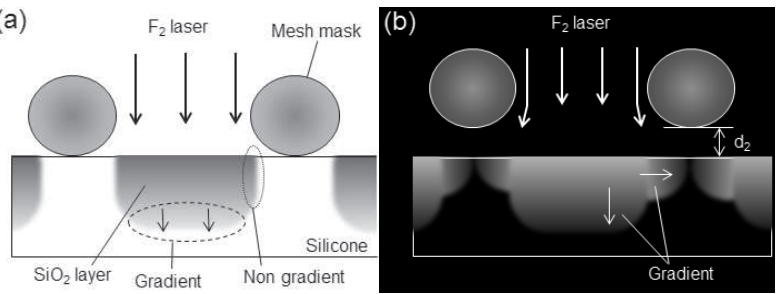

Fig. 5 Schematic structures of laser irradiation through the mesh mask: (a) contact mesh mask (b) under spacing $d_{2}$ between mesh mask and sample surface.

て設置した場合である。Fig. 5(a)においては, メッシュ マスクの開口端部には改質部と未改質部の明確な境界が 生ずるが，梁さ方向については $\mathrm{SiO}_{2}$ のレーザー波長にお ける透過率が有限の值を有するため, 深くなるに従い $\mathrm{SiO}_{2}$ からシリコーンの組成に暫時的に変化する傾斜組成 が形成される，著者らのこれまでの研究では， $\mathrm{F}_{2} レ$ ザーの照射時間を増していくと $\mathrm{SiO}_{2}$ 改質層の厚さ は1.3 $\mu \mathrm{m}$ 付近で飽和することがわかっており ${ }^{17)}$, この結 果から波長 $157 \mathrm{~nm}$ にお敞吸収係数は7700 $\mathrm{cm}^{-1}$ 程度 と推測される. 以上のことから, 深さ方向については傾 斜組成により応力が緩和されるが, 表面近傍の水平方向 の改質部境界には, 強い引張応力が発生しているものと 考えられる。一方Fig. 5(b)は, 距離 $d_{2}$ を設けることによ り, レーザー光を回折させ, マスクの開口端部に傾斜組 成を付与することにより，この部分に生ずる応力を低減 するようにしたものである。これにより， $\mathrm{SiO}_{2}$ 改質層の 厚さが増加しても応力は抑制された状態を保ち, レー ザー照射時間によらず良好な耐摩耗性を発現するものと 期待した.

そこで次に, $150 \mu \mathrm{m}$ のッシュマスクを使用し,

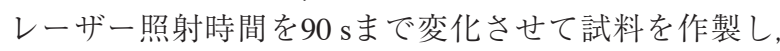
テーバー摩耗試験を行った. Fig. 6 は, $d_{2}$ が $0 \mathrm{~mm}$ と20 mmの場合について, $\Delta H_{1000}$ のレーザー照射時間依 存性を示した結果である。 $d_{2}$ が $20 \mathrm{~mm}$ の場合には, レー ザー照射時間が $90 \mathrm{~s}$ にいても $\Delta H_{1000}$ は $2 \%$ 以下の良好な 耐摩耗性を示した。

\subsection{FT-IR測定結果}

Fig. 7 に, メッシュマスクと試料表面の距離 $d_{2}$ が, (a) $0 \mathrm{~mm}$ と (b) $20 \mathrm{~mm}$ 場合において, 試料表面のFT-IR

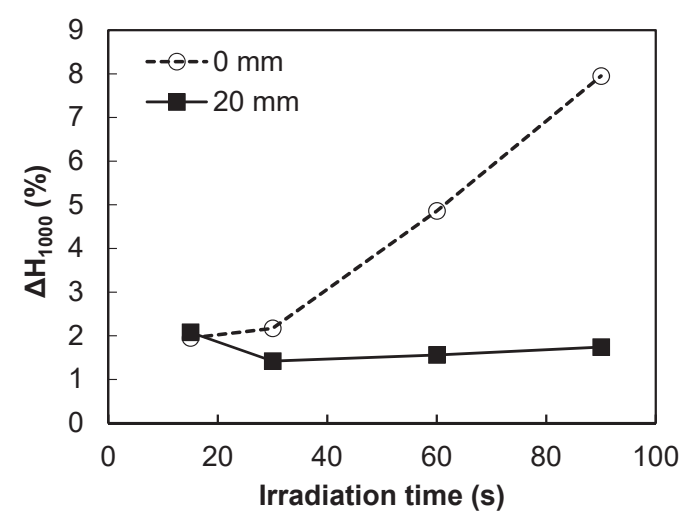

Fig. 6 Result of Taber abrasion test when changing space $d_{2}$. (a)

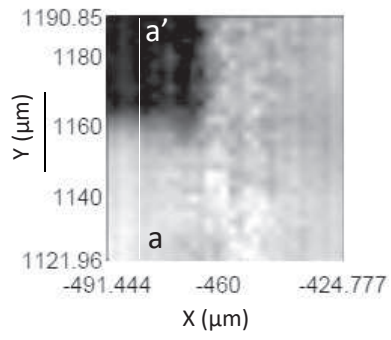

(b)

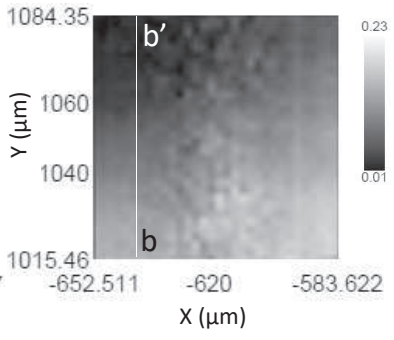

Fig. 7 Grayscale maps by FT-IR imaging when changing space of $d_{2}$ : (a) $d_{2}=0 \mathrm{~mm}$, (b) $d_{2}=20 \mathrm{~mm}$.

のイメージング測定を行った結果を示す。このときの

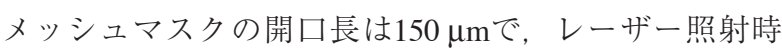
間は90 sであった。メッシュマスクの開口部が図中の左 上にあり，この部分が $\mathrm{SiO}_{2}$ に改質されている. $\mathrm{SiO}_{2}$ は濃 色で表示されシリコーンの組成に近くなるほど淡色に変 化するように表示されている。この結果によれば, $d_{2}$ が0 mmの場合には, メッシュマスクの開口部すなわち $\mathrm{SiO}_{2}$ とシリコーンの境界が明確に判別できる。これに対 し $d_{2}$ が2 $20 \mathrm{~mm}$ の場合には境界が不明瞭であり，境界付近 の組成が暫時変化していることが明らかである.

Fig. 8 に, Fig.7 中のa-a’およびb-b’ラインに沿った 線分析結果を示す。横軸に距離, 縦軸にSi-O結合の吸収 ピークの波数を示す。シリコーンの吸収ピーク が $1020 \mathrm{~cm}^{-1}$ 付近に現れるのに対し, $\mathrm{SiO}_{2}$ は $1055 \mathrm{~cm}^{-1}$ 付近 に生ずる。 $d_{2}$ が $0 \mathrm{~mm}$ の場合には, 距離が $37 \mu \mathrm{m}$ 付近で急 峻な組成変化を示しているのに対し， $d_{2}$ が20 mmの場合 は，70 $\mu \mathrm{m}$ の測定範囲の全体にわたり，ほぼ直線的に組 成が変化していることが明らかとなった。

以上のことは，距離 $d_{2}$ を大きくすることにより，レー ザー光の回折によるメッシュマスクの格子部直下におけ る試料表面の水平方向の傾斜組成化と, これに伴う引張 応力の緩和, および $\Delta H_{1000}$ の低下と安定化がもたらされ, これがFT-IRによるイメージング測定において亭付けら れた。

\section{4 フッ酸エッチングによる $\mathrm{SiO}_{2}$ 改質層の深さプロ ファイル}

Fig. 9 に, HF水溶液による $\mathrm{SiO}_{2}$ 改質層の化学エッチン グ後の, メッシュマスクの開口部付近の光学顕微鏡観察

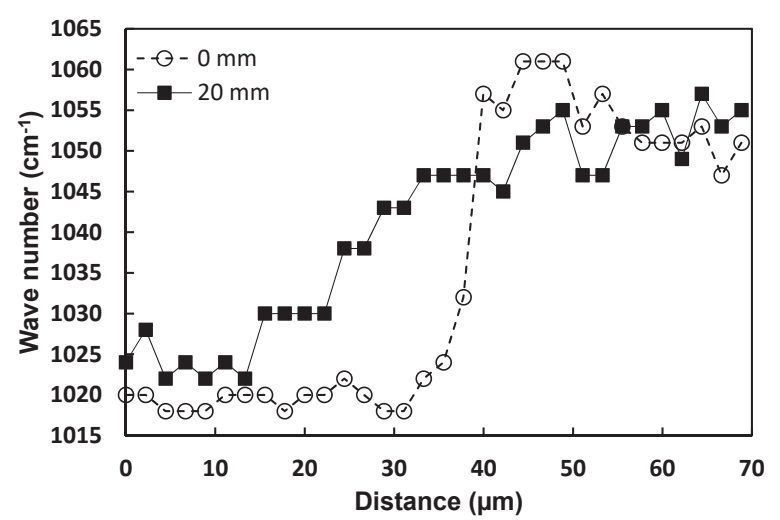

Fig. 8 Si-O absorbance peak changing depends on $d_{2}$. 


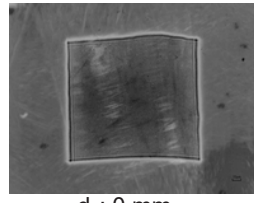

$\mathrm{d}_{2}: 0 \mathrm{~mm}$

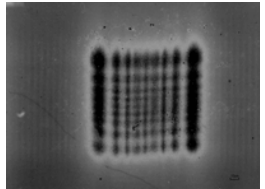

$5 \mathrm{~mm}$

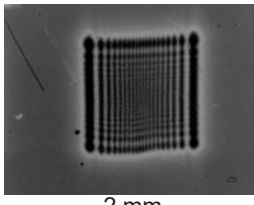
$2 \mathrm{~mm}$

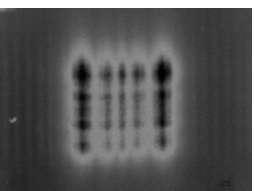

$10 \mathrm{~mm}$

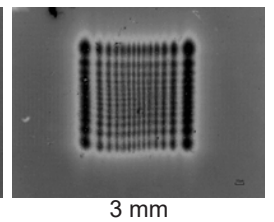

$3 \mathrm{~mm}$

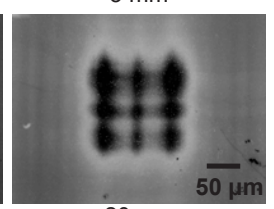

$20 \mathrm{~mm}$
Fig. 9 Micro photos HF etched surface depend on distance $d_{2}$ between mask and sample surface.

結果を示す。 $d_{2}$ が $0 \mathrm{~mm}$ の場合には明瞭な境界が認めら れたが， $d_{2}$ が大きくなるに従い境界部は不明瞭になり， さらに光学干渉により $\mathrm{SiO}_{2}$ 改質層の厚さにうねりが生じ ていることが明らかである。

Fig. 10 に $\mathrm{SiO}_{2}$ 改質層を化学エッチングにより除去した 後の段差測定結果を示す。メッシュマスクと試料表面の 距離 $d_{2}$ が大きいほど, 段差部が緩やかな形状に変化して いる様子が示されている. 深さは $\mathrm{SiO}_{2}$ の膜厚に相当す る。ここで, 距離 $d_{2}$ が大きいほど, $\mathrm{SiO}_{2}$ 改質層の厚さが 減少していることが明らかとなった。これは, 回折によ りレーザー光がマスク開口部の外側に広がったため, エ ネルギー密度が低下し, 結果として改質層が浅くなった ものと考えられる。 $d_{2}$ を $20 \mathrm{~mm}$ とし場合， $d_{2}$ はメッ シュマスクの開口長 $156 \mu \mathrm{m}$ に対し十分に大きな值であ るため, フラウンホーファー回折が起こっていると考え られる。このときの回折角は約 $0.06^{\circ}$ であり, 試料表面 では約 $20 \mu \mathrm{m}$ の周期でレーザー光が強め合うことにな る。これは, Fig. 9 の写真中に認められる干渉縞からも 示唆される。

\section{4. まとめ}

PC上に湿式法により塗布したシリコーン樹脂表面に, 波長157 nmのF $\mathrm{F}_{2}$ レーザーを照射することにより，その表

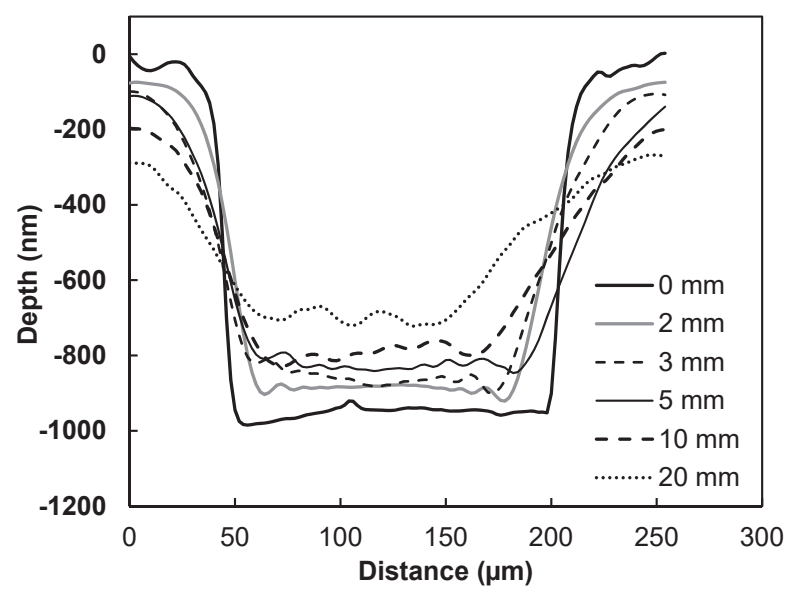

Fig. 10 Cross sectional profile of etched $\mathrm{SiO}_{2}$ modified layer.
面を光化学的に改質し $\mathrm{SiO}_{2}$ 膜を得た. $\mathrm{SiO}_{2}$ の膜厚増加に 伴い耐摩耗性は改善したが, さらにレーザー光を照射し 膜厚が増加すると, 逆に耐摩耗性が低下した。メッシュ マスクを介してレーザー光を照射し，かつメッシュマス クの開口長を小さくすることにより耐摩耗性の低下を抑 制できることが明らかとなった。 さらに，メッシュマス クと試料表面の距離を大きくすることにより，試料表面 上に光学回折による傾斜組成を形成し, 試料表面に生ず る光改質に伴う応力を抑制した結果，レーザー照射時間 によらず良好な耐摩耗性が得られることを明らかにし た。これにより, 自動車用の空材に規定されるテーバー 摩耗試験において, 安定して $\Delta H_{1000} \leqq 2 \%$ を達成できるこ とが示された，光化学改質を利用した自動車用空材の PC化は, 車両の軽量化を推進しデザインの自由度向上 をもたらすための要素技術として, 次世代自動車の開発 に大きく貢献するものと期待される.

\section{謝 辞}

本研究は, JSPS科研費16K06754の助成を受けて行わ れました。また，FT-IRのイメージング測定において， 広島県立総合技術研究所西部工業技術センターの小島 洋治主任研究員に協力をいただきました。厚く御礼申し 上げます。

\section{参考文献}

1) E. D. Lipp and A. L. Smith: in Chemical Analysis, ed. A. L. Smith (Wiley, New York, 1991) Vol. 112, p. 305.

2) A. T. Wolf: in Durability of Building Sealants, ed. A. T. Wolf (RILEM, Bagneux, 2000) p. 253.

3) J. P. Mollie: in Plastics for Electronics, ed. M. Goosey (Springer, Dordrecht, 1999) p. 25.

4) M. J. Owen: Chemtech 11 (1981) 288.

5）堀 洋一：EV·PHVロードマップ検討会報告書, 経済産業省 製造産業局自動車課・次世代技術·ITS推進室 (2016).

6) 林 達彦：日経オートモーティブテク)ロジー（日経BP, 東 京, 2009)p. 82 .

7) 黒田 浩次：繊維工学 44 (1991) 227.

8) W. Boentoro, A. Pflug, and B. Szyszka: Thin Solid Films 517 (2009) 3121.

9) E. S. Anand, S. R. Marur, J. Wittbrodt, and R. King: International Journal of Adhesion \& Adhesives 27 (2007) 338.

10) 中田 道生：高分子 46 (1997) 558.

11) 井上成美, 大越昌幸：材料の科学と工学 43 (2006) 125 .

12) H. Takao, M. Okoshi, and N. Inoue: Jpn. J. Appl. Phys. 41 (2002) 1088.

13) M. Okoshi and W. S. Pambudi: Appl. Phys. Express 9 (2016) 112701.

14) H. Nojiri, W. S. Pambudi, and M. Okoshi: Jpn. J. Appl. Phys. 56 (2017) 072002.

15）野尻 秀智, ウイスヌ セティオパンブディ, 大越昌幸：日 本赤外線学会誌 27 (2017) 50.

16) Y. Nojima, M. Okoshi, H. Nojiri, and N. Inoue: Jpn. J. Appl. Phys. 49 (2010) 072703.

17）大越昌幸：電気学会論文誌C 135 (2015) 1071 。

18）野尻秀智, 岩井和史, 中村先男, 井上成美, 大越昌幸, 萩原 健司, 植田 博臣, 新中 新二：プラスチック成形加工 学会誌 29 (2018) 30.

19) H. Nojiri and M. Okoshi: Jpn. J. Appl. Phys. 55 (2016) 122701.

20) H. Nojiri and M. Okoshi: Jpn. J. Appl. Phys. 56 (2017) 085502.

21）野尻秀智, 大越昌幸：レーザー研究 45 (2017) 646.

22) UNECE regulations No. 43 Rev. 3 (2012). 